\title{
IMPACT OF CELEBRITY ENDORSEMENT ON BRAND EQUITY
}

\author{
Seyed Ibne-Ali Jaffari, Farooq Ahmad, Muhammad Mehtab, Asif Iqbal \\ Assistant Professor, Business Administration Department \\ Federal Urdu University Arts Science \& Technology, Islamabad \\ Seyedjaffari5@yahoo.com, ibnealijaffari@fuuastisb.edu.pk \\ PhD Scholar marketing \\ Islamic International University, Islamabad \\ Lecturer, Business Administration Department \\ Federal Urdu University Arts Science \& Technology, Islamabad \\ hellowyoungman@yahoo.com \\ MS-Scholar \\ Federal Urdu University Arts Science \& Technology, Islamabad
}

\begin{abstract}
This research intends to explore the empirical relationship between endorser's credibility and consumer based brand equity in the presence of mediating role of brand credibility and moderating role of type of celebrities i.e. National or International was also examined. This paper uses two theories to explain the relationship; associative learning was used to explain the relationship between endorser and brand equity, and brand signaling to explain the relationship about the mediating role of brand credibility. The data was collected from Islamabad, the Federal capital of Pakistan and analyzed using SPSS. Results suggest that endorser's credibility has positive impact on brand equity and brand credibility mediates this relationship. The moderating role of type of celebrity was also discussed in this paper. The past literature suggests that celebrity endorser is one who is perceived as attractive, expert and trustworthiness. This research study examined the relationship of construct in the context of non-durable goods and measured the effectiveness of celebrity i.e. National or International proved to build brand equity.
\end{abstract}

decpak@yahoo.com

Key Words: Brand equity, endorser's credibility, brand credibility, non-durable goods

\section{Academic Discipline and Sub-Disciplines}

Management Sciences, Marketing

\section{SUBJECT CLASSIFICATION}

Social Science

TYPE (METHOD/APPROACH)

Survey/Interview

\section{Council for Innovative Research}

Peer Review Research Publishing System

Journal: International Journal of Management \& Information Technology

Vol. 10 No. 3

editorsijmit@gmail.com

www.ijmit.com/ojs 


\section{INTRODUCTION}

It had been observed through past research that endorsement made by celebrities have positive impact on brand recognition, brand recall, purchase intentions and even purchase behaviour. The research conducted recently has proved that celebrity endorsement leads to a favorable attitude towards the endorsed brand (Till et al., 2008), but little or even no evidence is available on whether National celebrity or International celebrity having similar impact on brand equity in the local market. Past researchers have found the relationship of endorser's credibility on brand equity on durable goods but the same relationship has not empirically been proved and verified on non-durable goods.

The term brand equity refers to the incremental value added by a brand name to a product (Farquhar, 1989). It is widely accepted that communication using different mediums usefuly builds brand equity (Keller, 2005) and endorser's credibility add value in s brand building brands specially brand equity (Keller, 1993). Past research has proved that spokesperson's credibility increase brand credibility and consequently brand equity. It is unclear whether the endorsement by national celebrity and international celebrity results into a similar impact on brand credibility in the local market or otherwise. Secondly research studies conducted in the past also explored the impact of endorser's credibility on brand equity of durable goods whereas non-durable goods are still unexplored. This attempted to measure the impact of both national and international endorser's credibility on brand equity. Can celebrity endorsement leads to brand equity? McCracken (1989) have suggested that celebrity endorsers can build brand equity by creating secondary associations.

Seno and Lukas (2007) proposed that a celebrity endorser operates as a co-brand for the endorsed brand resulting in creation of equity for both the endorsed brand and the endorsing celebrity. It is empirically proven that celebrity endorsement enhances recall value for the brand which is endorsed and also creates greater recall for those advertisements which were endorsed by the credible celebrity (Atkin and Block, 1983). Research has also shown that celebrity endorsement can influence perceived product quality and uniqueness (Dean, 1999). Ranjbarian et al., 2010 suggested that attitude toward celebrity endorser can influence on attitude toward brand directly or indirectly.

\section{Literature Review}

Endorser credibility in the past literature is defined as "the extent to which the source is perceived as possessing expertise relevant to the communication topic and can be trusted to give an objective opinion on the subject" (Goldsmith et al, 2000 ; Ohanian, 1990). Marketing research scholars are agreed that brand equity in consumer's perspective is something which refers to "incremental value added by a brand name on to a product" (Farquhar, 1989). Aaker (1991) and Kaller (1993) explored two of the most commonly known conceptualization for brand equity. Aaker (1991) operationalized brand equity as brand awareness, brand association, perceived brand quality and brand loyalty while Kaller (1993) explained brand equity as consumer based brand equity and defined it as "the differential effect of brand knowledge on consumer response to the marketing of the brand". In consumer's context the dimensions of brand equity which were explored by Aaker (1991) i.e. brand awareness, brand association, perceived quality and brand loyalty are believed to be most important (Yoo et al., 2000). Yoo and Donthu (2001) have revisited the term consumer-based brand equity to refer to the set of these four brand equity dimensions. In the current paper the present approach is presented in the same context and consumer based brand equity is defined as "the value consumers associate with a brand, as reflected in the dimensions of brand awareness, brand associations, perceived quality and brand loyalty" (Pappu et al., 2006 ). According to Aaker (1991) the brand awareness means the image or power of the brand which is present in the consumer's gray matter. Brand awareness consists of brand recall and brand recognition whereas brand association refers to various meanings surrounding a brand (Kaller, 1993). Perceived quality is related the how consumer evaluate the brand (Zeithaml, 1988). Brand loyalty is considered in attitudinal perspective consumer based brand equity is not an actual behaviour performed by the consumer instead it is based on consumer perception. Brand loyalty is defined as "the propensity to be loyal to a focal brand which is evidenced by the intention to purchase that brand as a primary choice" (Yoo and Donthu, 2001).

Building brand credibility largely depends on information disseminated thorough various marketing strategies associated with the brand (Erdem and Swait, 1998). Celebrity endorsement is marketing tool to disseminate information to the target market, which comprises of some signals to the market about that particular brand being endorsed. It gives an impression that the endorser's credibility will subsequently be transferred to the endorsed brand. Brand credibility helps to build consumer based brand equity, brand signaling theory supports the argument that credibility helps to support consumer based brand equity (Erdem and Swait, 1998). Credible brand enjoys lower information and information-processing costs and lower perceived risks (Erdem and Swait, 1998). Associative network memory model suggests that celebrity endorsement can support to create brand recall and brand recognition. A highly credible endorser will become more strongly associated with the endorsed brand in consumer's gray matter (Biswas et al., 2006). Managing brand equity largely involves controlling the meanings associated with a brand in memory (Keller, 1993). When a celebrity endorses a brand, consumer not only associate the celebrity with the brand but consumer also feel the link of celebrity association with the endorsed brand leading to create a larger network of association. Celebrities work as extrinsic cue which transfers information on product attributes, product quality leading to a reduced risk of uncertainty and help consumer to take decision about their preferences (Dean, 1999).

\section{CONCEPTUAL FRAMEWORK}

The conceptual framework employed in this study is based on the two theories; associative network memory model from cognitive psychology and brand signaling theory which forms the basis of information economics. Associative network memory is used to briefly explain the relationship between endorser's credibility and brand equity while Brand signaling 
theory is employed to explain the mediating role of brand credibility in the context of endorser's credibility and brand equity. The moderating role of type of celebrity (National vs. International) on non-durable goods will also be considered.

Figure 1

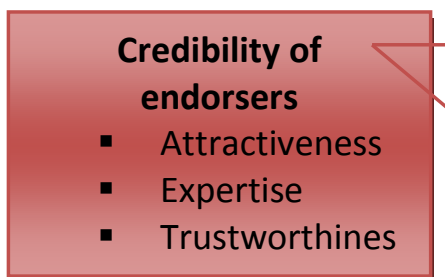

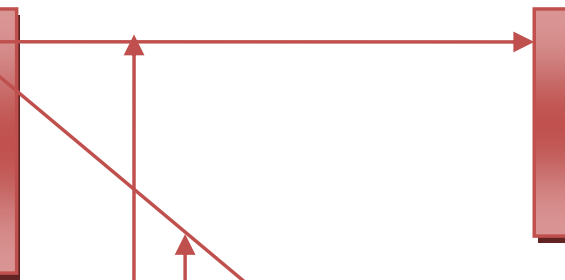

\section{Brand credibility}

- Expertise

- Trust worthiness

- Trustworthines

\section{Hypothesis}

On the basis of conceptual framework discussed above, six hypotheses were graduated:

$\mathrm{H} 1$ : $\quad$ there is positive impact of endorser credibility on Brand credibility

$\mathrm{H} 2$ : $\quad$ there is positive impact of $\mathrm{BC}$ on $\mathrm{BE}$ of endorsed brand

H3: $\quad$ there is positive impact of endorser credibility on Brand equity

H4: $\quad$ BC mediates the relationship between endorser's credibility and brand equity.

H5: The relationship between EC and BC varies according to type of celebrity i.e. National or International

H6: The relationship between EC and consumer based brand equity varies according to type of celebrity i.e. National or International

\section{Methodology}

The relationship between endorser's credibility, brand credibility and brand equity was examined by employing a field experiment in Islamabad, the Federal Capital of Pakistan. Data were collected using a questionnaire from the respondents having ages 18 and or above. Endorser's credibility was manipulated at two levels (National celebrity vs. International celebrity). This study design aimed to study the impact of National or International celebrity credibility on brand equity. So to address this study design two print ads were developed using two celebrities separately in each print media advertisement to measure impact of celebrity's endorsement on brand equity. Each respondent was assigned to single print advertisement only. Every questionnaire was attached with one print advertisement. The advertisements were featured with different manipulations which were selected using various phases amongst the University students. As this study was conducted to explore the impact of endorser's credibility on brand credibility and brand equity of non-durable goods, therefore, Havoline formula engine oil, a Caltex brand, was selected as a product category for this research study.

\section{Celebrity:}

The endorsers which were present in the print advertisement were selected though various phases of pretesting using convenient sampling method and consisted of graduate students. The students who participated in the first phase of pretesting were given 3-5 minutes to write down the name of sports celebrities of their own choice who they felt were most suitable endorser for the Havoline formula engine oil. This was done to achieve congruence level between the celerity credibility and endorsed brand. During the exercise of first phase of pretesting a pool of 90 celebrities was generated. From the initial pool of sports celebrities selection some celebrities were eradicated because identified control variable believed to influence the effectiveness of celebrity endorsers. First of all, all the female sports celebrities were eliminated as recent research shows that male and female celebrities are evaluated differently by the consumers. For example, those ads in which female celebrities appeared are evaluated more favorably by the consumers than those advertisements in which male celebrities appeared (Klaus and Bailey, 2008). Previous research also recommends that male celebrities are more appropriate with functional products (Stafford et al., 2003). Therefore, female celebrities were eliminated from the initial pool of 90 celebrities. During the second round, celebrities who had previously/ recently endorsed other products 
were also eliminated as it is acknowledged that those celebrities can effect consumer evaluation about endorsers and endorsed brands (Goldsmith et al., 2000). It is not easy to establish an associative link between the brand and endorser when the same endorser is already linked with another brand or the product (Till, 1998). During the last stage of celebrities reduction, those celebrities were also eliminated who had got negative publicity in the past as negative information is considered to be harmful and effects consumer's perception about the endorsed brands (Louie et al., 2001; Till and Shimp, 1998). The remaining celebrities were both national and International cricketers, footballers, tennis stars and hockey players. The reduced list of 10 celebrities was further examined using questionnaire of convenience sample of 20 respondents.

Descriptive statistics

\begin{tabular}{llllll}
\hline Name of player & $\mathrm{N}$ & Minimum & Maximum & Mean & Std. Deviation \\
\hline Jahangir khan & 20 & 4.40 & 5.40 & 4.8133 & .38547 \\
$\underline{\text { Zaidane }}$ & $\underline{\mathbf{2 0}}$ & $\underline{\mathbf{4 . 6 0}}$ & $\underline{\mathbf{5 . 8 0}}$ & $\underline{\mathbf{4 . 9 8 6 7}}$ & $\underline{\mathbf{. 4 4 8 3 1}}$ \\
$\underline{\text { Aisam-ul-Haq }}$ & $\underline{\mathbf{2 0}}$ & $\underline{\mathbf{4 . 5 3}}$ & $\underline{\mathbf{6 . 2 7}}$ & $\underline{\mathbf{5 . 3 0 6 7}}$ & $\underline{\mathbf{. 6 5 4 0 6}}$ \\
Bret Lee & 20 & 3.67 & 5.00 & 4.6400 & .51112 \\
Sohail Abbas & 20 & 4.07 & 5.80 & 4.8267 & .65691 \\
Shahbaz Senior & 20 & 3.00 & 4.60 & 4.1333 & .60871 \\
Sanga kara & 20 & 3.93 & 5.07 & 4.4000 & .48365 \\
Maligna & 20 & 3.53 & 4.47 & 4.0800 & .33620 \\
Umer gul & 20 & 4.00 & 5.00 & 4.4533 & .34984 \\
M. Hafiz & 20 & 3.80 & 5.60 & 4.4000 & .68672 \\
\hline Valid N (list wise) & 20 & & & &
\end{tabular}

The questionnaires along with photographs of selected national and international celebrities were administered to the respondents to measure credibility of each celebrity on seven pint scale. Data were processed using SPSS to measure mean value of each celebrity. First the items were computed and then score on items of various celebrities were averaged to calculate the mean of each celebrity. On the basis of pre-test results two celebrities i.e. one National and one International were selected. From the list of National celebrities Mr. Aisam-ul-Haq, a growing tennis star from Pakistan, was identified as high credible celebrity $(M=5.3067)$, while on International side Mr. Zaidane, a famous footballer, was identified as high credible celebrity $(\mathrm{M}=4.9867)$ as depicted in Table 1.

\section{Data collection}

Data were collected on a questionnaire from the respondents of age 18 and or above years. Endorser's credibility was manipulated at two levels (National celebrity vs. International celebrity). This study design was resulted in two different conditions i.e. the impact of National or International celebrity credibility on brand equity. Model town, Blue Area, and a key shopping mall at Islamabad were selected as the convenient sampling area for the study. Data was collected using a systematic sampling technique. Two data collection instruments one for National celebrity and the other for International celebrity were developed to measure the hypothetical relationship among the selected research variables. The questionnaire included the questions related to endorser's credibility, brand credibility and consumer based brand equity.

\section{Measure and Measurement}

Tested, reliable and credible measurement were used in this study, measurement sale were adopted from the past research. Endorser's credibility was measured using three sub dimensions, as attractiveness, expertise and trustworthiness as mentioned in the source model theory (La Ferle and Choi, 2005; Ohanian, 1990). Expertise refers to the extent to which an endorser is perceived to hold valid statement about the endorsed brand. While trustworthiness refers to the degree of confidence in the endorser's intention to communicate statement about endorsed brand considered to be most valid (Hovland et al., 1953). Endorser which is physically attractive enough can have influence to change the opinion and at the same time can influence on product evaluation (Hovland et al., 1953). To measure endorser's credibility a tested scale was used which was developed by Ohanian (1990), which measure celebrity credibility and three sub dimensions, attractiveness, expertise and trustworthiness. The sub dimensions of endorser's credibility were measured using seven point semantic differential scales.

Brand credibility with two sub dimensions, expertise and trustworthiness considered on past research. Measure of brand credibility was taken from brand signaling literature (Erdem and Swait, 2004). Two dimensions of brand credibility were measured using seven items on a seven point Likert scale where, "7 mean strongly agree" and " 1 mean strongly disagree". 
Consumer based brand equity was considered as four dimensional construct including brand awareness, brand association, perceived quality and brand loyalty. Seven point Likert scale whereas "7= strongly agree" and " $1=$ strongly disagree". Three items of brand awareness was measured using the scale developed by (Yoo and Donthu, 2001). The second dimension of brand equity, brand association, was measured using five items developed by (Aaker, 1991). Third dimension of consumer based brand equity, perceived quality, was measured using five items originally suggested by (Aaker 1991) and later on the same scale was also used by Yoo and Donthu, 2001. Finally, the last dimension, brand loyalty, was measured using five items scale developed by Yoo and Donthu, 2001 and same scale was used by many other scholars in the past.

Past research shows that covariates influence the spoke person's endorsement (Silvera and Austad, 2004; Till, 1998) so on account of covariate, endorser's familiarity, brand familiarity, celebrity-brand congruence and product knowledge were also included in this study. Measure of endorser's familiarity, brand familiarity was measured using three items on seven point semantic differential scale developed by Simonin and Ruth (1998). Celebrity-brand congruence was measured using three items on semantic differential scale as mentioned by Aaker and Kaller (1992). Product knowledge was measured using three items on seven point Likert scale developed by Cole and Balasubramanian (1993).

\section{DATA ANALYSIS AND RESULTS}

In the total sample of 208 respondents higher portion was meal respondents as compared to female respondents (93\% Vs $7 \%$ ). Overall sample was skewed towards yonder consumers $67 \%$ respondents were in age bracket 21-29 years.

\section{Reliabilities of scales used in the study}

As established scales were used in the present study hence reliabilities of the scale were measured using conventional method i.e. Chronbach's alpha was calculated to get $\alpha$ values of items related to various variables. The $\alpha$ values of all the constructs exceeded suggested cut of values i.e. 0.73 as shown in the Table 1 except brand loyalty, fourth dimension of consumer based brand equity, the Chronbach's alpha of brand loyalty is 0.61 .

Table 1 :

Cronbach's Alpha

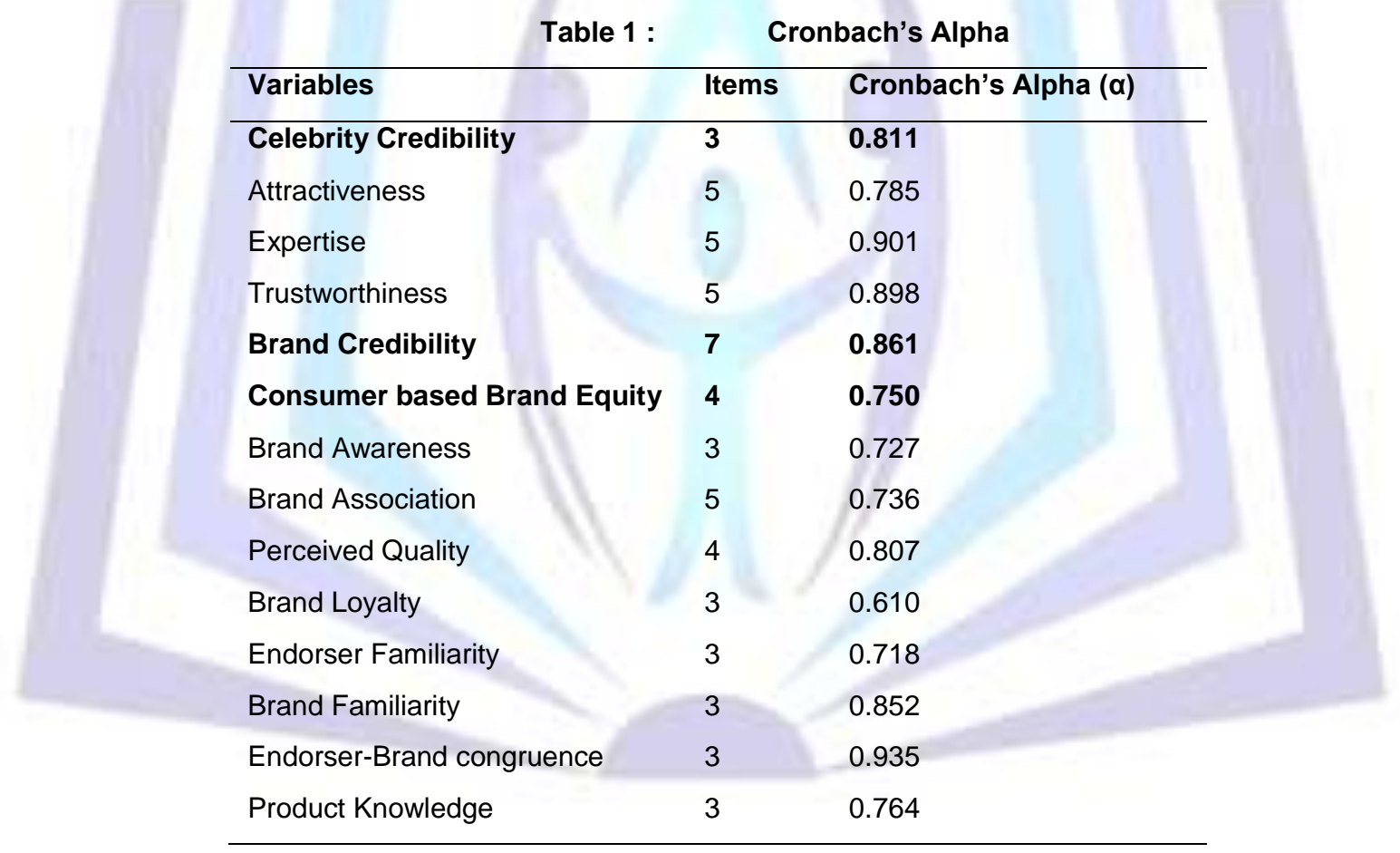


Table 2 presents Mean values, standard deviation and correlation amongst the key variables of this study.

\begin{tabular}{|c|c|c|c|c|c|c|c|c|c|}
\hline Variables & Mean & SD & 1 & 2 & 3 & 4 & 5 & 6 & \\
\hline Endorser Credibility & 5.0862 & .99520 & 1 & & & & & & \\
\hline Brand Equity & 5.1876 & .74367 & $.481^{\pi \pi}$ & 1 & & & & & \\
\hline Endorser Familiarity & 6.2468 & .84809 & $.156^{*}$ & $.335^{* *}$ & 1 & & & & \\
\hline Brand Congruence & 5.1827 & 1.50639 & $.420^{\pi \pi}$ & $.305^{\pi \pi}$ & $.222^{\pi x}$ & 1 & & & \\
\hline Product knowledge & 4.3045 & 1.21417 & $.189^{\pi \pi}$ & $.140^{\circ}$ & -.032 & -.025 & 1 & & \\
\hline Brand Familiarity & 5.7885 & 1.15243 & $.188^{\pi \pi}$ & $.289^{\pi \pi}$ & $.384^{\pi \pi}$ & .130 & $.405^{\pi \times}$ & 1 & \\
\hline Brand credibility & 5.1607 & .94044 & $.689^{\pi \pi}$ & $.638^{\pi \pi}$ & $.172^{\pi}$ & $.308^{\pi \pi}$ & $.359^{\times \pi}$ & .095 & 1 \\
\hline
\end{tabular}

To test the hypothesis statistical package for social science (SPSS) was employed. At the first stage one way ANOVA test was conducted with both the celebrities i.e. National and International to access the direct effect of endorser's credibility (independent variable) on brand equity brand credibility (dependent variable) and indirect effect of endorser's credibility via brand credibility on brand equity was examined. The results of one way ANOVA as depicted in Table 3 indicated that the direct effect of endorser's credibility on consumer based brand equity which clearly indicates that there is significantly difference between direct effect models vs. indirect effect model, direct effect model. Direct effect model is predicted as $(F$ $[1,206]=62.17, p<.01)$ while indirect model is predicted as $(F[1,205]=71.19, p<.01)$.

In the direct effect model results shows that independent variable endorser's credibility has $48 \%$ correlation ( $R=.481)$ and proportion of variation in independent variable has $23 \%\left(R^{2}=.232\right)$, while beta value $(\beta=.481)$ indicates that one unit increase in endorser credibility will increase Brand Equity by $48 \%$. Similarly $t=7.88$ is significant at $.000(P=.000<.05)$ hence our hypothesis H3: There is positive impact of endorser credibility on Brand equity is accepted and concludes that endorser credibility having positive impact on brand equity.

In the indirect model i.e. impact of endorser's credibility via brand credibility on brand equity has assessed here results indicates that independent variable endorser's credibility has $64 \%$ correlation ( $R=.640$ ) and proportion of variation in independent variable has $41 \%\left(R^{2}=.410\right)$, while beta value $(\beta=.582)$ indicates that one unit increase in endorsers' credibility will increase Brand Equity by $58 \%$. Similarly $t=7.864$ are significant at $.000(P=.000<.05)$ hence mediation of brand credibility is proved so our hypothesis $\mathrm{H} 4$ : Brand credibility mediates the relationship between endorser's credibility and brand equity is accepted. So it is concluded that brand credibility strengthen the relationship of endorser's credibility and brand equity. Endorser credibility-brand credibility is positive and statistically significant $(\beta=.68, p<.001)$ supporting $\mathrm{H} 1$ i.e. There is positive impact of endorser's credibility on brand equity is accepted. Brand credibility and brand equity relationship is also positive and statistically significant $(\beta=.63, p<.001)$ which support $\mathrm{H} 2$ saying there is positive impact of brand credibility on brand equity.

\section{Results for the moderating role of type of endorser (National vs. International)}

To measure the moderating role of type of celebrity i.e. National or International direct effect and indirect effect relationship was accessed. The relationship between EC and BE varies according to type of celebrity i.e. National or International

one way ANOVA test was conducted with both the celebrities i.e. National and International to access the direct effect of endorser's credibility (independent variable) on brand equity (dependent variable) and indirect effect of endorser's credibility via brand credibility on brand equity was examined. The results of one way ANOVA indicated that there is significant difference in the construct in context of National or International celebrity. The value for direct effect of National endorser's credibility on consumer based brand equity is $(F[1,150]=45.68, p<.01)$ while indirect model is predicted as $(F$ $[1,149]=49.22, p<.01)$. The value for direct effect of International endorser's credibility on consumer based brand equity is $(F[1,54]=17.59, p<.01)$ while indirect model predicted as $(F[1,53]=38.78, p<.01)$ which clearly indicates that both the situation are significantly different. 
Table 3

\begin{tabular}{llllll}
\hline Celebrity & $\mathbf{R}$ & $\mathbf{R}^{\mathbf{2}}$ & $\mathbf{B}$ & $\mathbf{T}$ & $\mathbf{P}$ \\
\hline Notational & & & & & \\
Direct effect & $.483^{\mathrm{a}}$ & .233 & .483 & 6.756 & .000 \\
Indirect effect & $.592^{\mathrm{b}}$ & .350 & .484 & 5.171 & .000 \\
International & & & & & \\
Direct effect & $.496^{\mathrm{a}}$ & .246 & .496 & 4.195 & .000 \\
Indirect effect & $.771^{\mathrm{b}}$ & .594 & .770 & 6.744 & .000 \\
\hline
\end{tabular}

Table 3clearly indicated that endorser's credibility, brand equity and endorser's credibility, brand credibility and band equity varies with the level of endorser i.e. International or National in the local market. This type of relationship of endorser's credibility on brand credibility and brand equity has not been explored so far in the brand streams. So this support our both the hypotheses i.e. $\mathrm{H} 5$ and $\mathrm{H} 6$.

\section{CONCLUSION}

The result highlighted in this research paper showing a positive and significant relationship between endorser's credibility and brand credibility which support $\mathrm{H} 1$ of this research. This type of relationship has limited familiarity amongst the research scholars and secondly this relationship has not been explored so far in the developing economies.

This research has also confirmed the relationship of brand credibility and consumer based brand equity which helps to strengthen past research findings, this support H2. Results also highlighted that relationship between endorser's credibility, brand credibility and brand equity varies by the type of celebrity employed i.e. national or International, this type of relationship and finding was not explored in the brand literature in the past which support hypotheses H5 \& H6. This research provided the empirical evidence of endorser's credibility on brand equity in context of non durable goods i.e. engine oil which is also the contribution towards the existing knowledge of brand streams.

This research showed that both the National celebrity and International celebrity provided the support for building brand equity. Table 3 depicted that International celebrity exceeds in the values like $R, R^{2}, \beta, t$ values, there are several possible explanations for this results. Respondents were exposed to print ad and "Zidane", a football legend, having very popularity across the world including in Pakistan. Second possible reason may be the brand which was selected for this study i.e. Havoline Formula most probably this brand has also edge over other brands falls in the same category. Respondents strongly associate the brand due it its superior quality and performance with the International known footballer.

H4 predicted that brand credibility mediate the relationship between endorser's credibility and brand equity, this study supported this relationship as well. The present study also supported the previously explored theorized relationship between endorser's credibility and brand equity.

\section{REFERENCES}

1. Aaker, D.A. (1991), Managing Brand Equity, The Free Press, New York, NY.

2. Atkin, C. and Block, M. (1983), "Effectiveness of celebrity endorsers," Journal of Advertising Research, Vol. 23 No. 1, pp. 57-61

3. Biswas, D., Biswas, A. and Das, N. (2006), "The differential effects of celebrity and expert endorsements on consumer risk perceptions," Journal of Advertising, Vol. 35 No. 2, pp. 17-31

4.Dean, D.H. (1999), "Brand endorsement, popularity, and event sponsorship as advertising cues affecting consumer pre-purchase attitudes," Journal of Advertising, Vol. 28 No. 3, pp. 1-12

5. Erdem, T. and Swait, J. (1998), "Brand equity as a signaling phenomenon," Journal of Consumer Psychology, Vol. 7 No. 2, pp. 131-57

6. Farquhar, P. H. (1989), "Managing brand equity," Market Research, Vol. 1 No. 3, pp. 24-33

7. Goldsmith, R.E., Lafferty, B.A. and Newell, S.J. (2000), "The impact of corporate credibility and celebrity credibility on consumer reaction to advertisements and brands," Journal of Advertising, Vol. 29 No. 3, pp. 43-54

8. Keller, K.L. (1993), "Conceptualizing, measuring, and managing customer-based equity," Journal of Marketing, Vol. 57 No. 1, pp. 1-22

9. Keller, K.L. (2005), "Choosing the right brand elements and leveraging secondary associations will help marketers build brand equity," Marketing Management, Vol. 14 No. 5, pp. 19-23.

10. Klaus, N. and Bailey, A.A. (2008), Celebrity endorsements: An examination of gender and consumers' attitudes," American Journal of Business, Vol. 23 No 2, pp. 53-61. 
11. Louie, T. A., Kulik, R.L. and Johnson, R. (2001), "When bad things happen to the endorsers of good products," Marketing Letters, Vol. 12 No. 1, pp. 13-24

12. Ohanian, R. (1990), "Construction and validation of a scale to measure celebrity endorsers' perceived expertise, trustworthiness and attractiveness," Journal of Advertising, Vol. 19 No. 3, pp. 39-52

13. Pappu, R., Quester, P. and Cooksey, R.W. (2006), "Consumer-based brand equity and country-of-origin relationships: Some empirical evidence,” European Journal of Marketing, Vol. 40 No. 5-6, pp. 696-717.

14. Raajpoot, N.A., Sharma, A. and Chebat, J.C. (2008), "The role of gender and work status in shopping center patronage," Journal of Business Research, Vol. 61 No. 8, pp. 825-833.

15. Stafford, M.R., Spears, N.E. and Hsu, C. (2003), "Celebrity images in magazine advertisements: An application of the visual rhetoric model," Journal of Current Issues and Research in Advertising, Vol. 25 No. 2, pp. 13-20.

16. Till, B.D. (1998), "Using celebrity endorsers effectively: Lessons from associative learning," Journal of Product and Brand Management, Vol. 7 No. 5, pp. 400-09.

17. Till, B.D., Stanley, S.M. and Priluck, R. (2008), "Classical conditioning and celebrity endorsers: An examination of belongingness and resistance to extinction," Psychology and Marketing, Vol. 25 No. 2, pp. 179-76.

18. Yoo, B., Donthu, N. and Lee, S. (2000), "An examination of selected marketing mix elements and brand equity," Journal of the Academy of Marketing Science, Vol. 28 No. 2, pp. 195-211.

19. Zeithaml, V. (1988), "Consumer perceptions of price, quality, and value: a means-end model and synthesis of the evidence," Journal of Marketing, Vol. 52 No. 3, pp. 2-22. 